\title{
EVIDENCE ON THE EXISTENCE OF COMMON STOCK INFLATION HEDGES
}

\author{
Victor L. Bernard ${ }^{\star}$ and Thomas J. Frecka**
}

\begin{abstract}
Previous researchers have been unable to identify (on an ex ante basis) inflation hedge portfolios consisting of common stocks. This study demonstrates a procedure for forming common stock portfolios that offer returns that vary positively with unexpected inflation. The strategy could have been used to hedge against purchasing power risk during the 1974-1979 period. In addition to its practical value, the research has important implications for capital asset pricing theory since the existence of hedge portfolios is a necessary condition for the superiority of the multi-period CAPM over the single-period models.
\end{abstract}

\section{Introduction}

Although asset payoffs are in nominal terms, rational investors should seek investments that are efficient in real terms. However, initial versions of the capital asset pricing model (CAPM) by Sharpe (1964) and others were generally interpreted in nominal terms. Some extensions of capital asset pricing theory have dealt with wealth in real terms by introducing an asset called a hedge portfolio. For example, Long's (1974) multi-period CAPM shows that rational investors should hold, in addition to nominally risk-free bonds and the market portfolio, long (short) positions in portfolios used to hedge against (speculate on) unanticipated shifts in the price level and other factors affecting lifetime consumption. More recently, Manaster (1979) and Sercu (1981) have shown, in a single-period setting, procedures for transforming nominally efficient portfolios into real-efficient portfolios through the addition of an inflation hedge portfolio.

The purpose of this paper is to demonstrate the existence of common stock inflation hedge portfolios. To date, evidence on the existence of common stock inflation hedges is sparse. For example, Bodie (1976) demonstrates that a long position in the aggregate stock market can not be used to hedge against unanticipated inflation since the market index covaries negatively with unexpected inflation. However, the failure of the aggregate market to offer hedging potential does not mean that strategies employing appropriate combinations of individual securities cannot be successful. Schipper and Thompson (1981) combine long and short positions in certain common stocks in their hedging study. However, because their approach requires a stable relationship between stock returns and inflation over an extended period, the Schipper and Thompson strategy does not provide a good hedge against unexpected inflation.

The hedging strategy adopted in this paper conforms to most major aspects of the theories developed by Manaster (1979) and Sercu (1981) but places fewer demands on

*University of Michigan.

**University of Illinois, Urbana-Champaign.

Financial support for this research was provided by the University of Illinois Bureau of Economic and Business Research and by the Deloitte Haskins \& Sells Foundation. 
the data than the approach of Schipper and Thompson. As in the Manaster and Sercu analysis, the inflation hedge portfolio has a real return that (ignoring margin requirements) has an expected value of zero and that covaries positively with unexpected inflation. However, portfolio weights are not derived in strict conformity with the work of Manaster and Sercu because to do so would create the same problem of instability faced by Schipper and Thompson. Instead, the hedging strategy is based on two intuitively appealing characteristics, referred to in Section II as effectiveness and efficiency, that must be possessed by any inflation hedge portfolio.

Section II explains the characteristics of a successful hedging strategy and examines the hedging potential of both the market portfolio and individual stocks. A hedging strategy is then developed and is evaluated in terms of its ability to hedge against the risk associated with one particular nominally efficient portfolio: a portfolio consisting only of default-free fixed-income securities. Conclusions follow in Section III.

\section{Hedging Against Purchasing Power Risk in a Fixed Nominal Income Stream}

\section{Characteristics of a Successful Hedging Strategy}

Consider the return on a one-period, risk-free note that is fixed, in nominal terms, in the amount of $1+R$. The real return can be defined as $(1+R) /\left(1+i^{\prime}\right)$, where $i^{\prime}$ denotes the inflation rate and the prime $\left({ }^{\prime}\right)$ indicates a random variable. Although the nominal return is fixed, there exists some uncertainty concerning the real return since the inflation rate cannot be predicted with certainty. A measure of the risk associated with the real return is $\operatorname{Var}\left[(1+R) /\left(1+i^{\prime}\right)\right]$. Boonekamp (1978) and others have referred to this risk as purchasing power risk.

Assume that some portion of wealth is invested in a hedge portfolio that offers a real return $h^{\prime}$ characterized as follows:

$$
h^{\prime}=1+\bar{h}+b u^{\prime}+e^{\prime}
$$

where

$$
\begin{aligned}
u^{\prime} & =\text { unexpected inflation, } \\
e^{\prime} & =\text { error term, } \\
b & =\text { cov }\left(h^{\prime}, u^{\prime}\right) / \operatorname{Var}\left(u^{\prime}\right), \text { and } \\
\bar{h} & =\text { mean real return on hedge portfolio. }
\end{aligned}
$$

Equation (1) states that the deviation of the real return on the hedge portfolio from its mean can be separated into two components. The first component, $b u^{\prime}$, is a linear function of unexpected inflation, while the second component, $e^{\prime}$, is not correlated with unexpected inflation. There exist no restrictions on the value of $\bar{h}$; however, the strategy to be developed later will be constructed so that $\bar{h}$ equals zero. The portfolio can be used to hedge against purchasing power risk if 


$$
\operatorname{Var}\left[(1-w)\left[\frac{1+R}{1+i^{\prime}}\right]+w\left(1+h^{\prime}\right)\right]<\operatorname{Var}\left[\frac{1+R}{1-i^{\prime}}\right]
$$

where $w$ is the fraction of wealth invested in the hedge portfolio.

Within this context, Bodie (1976) has developed a measure of the risk-reducing potential of a hedge portfolio. The proportional reduction in total risk, $(S)$, that can be achieved by investing $w$ percent of wealth in the hedge is

$$
S=\frac{1}{\left[\frac{\operatorname{Var}\left(e^{\prime}\right)}{1+\operatorname{Var}\left(u^{\prime}\right)(1+R+b)^{2}}\right]}
$$

where

$$
w=\frac{(1+R)(1+R+b)}{(1+R+b)^{2}+\frac{\operatorname{Var}\left(e^{\prime}\right)}{\operatorname{Var}\left(u^{\prime}\right)}}
$$

(For details of the derivation of equations (3) and (4), see Bodie, 1976.) By combining the hedge portfolio with the investment in a fixed nominal income stream, risk is reduced to $(1-S) \operatorname{Var}\left[(1+R) /\left(1+i^{\prime}\right)\right]$.

Because $\operatorname{Var}\left(u^{\prime}\right)$ and $R$ must be taken as given by the investor, the value of the hedge depends only on $b$ and $\operatorname{Var}\left(e^{\prime}\right)$. In this paper, $b$ provides a measure of the eff $i$ ciency of the hedge and $\operatorname{Var}(e)$ provides a measure of the effectiveness of the hedge. As explained below with the aid of Figure I, a good hedge must be both efficient and effective.

Efficiency. From equation (3), the percentage reduction in total risk $(S)$ is higher, the greater is $b$. Furthermore, if $b$ is very high, then it will generally be possible to offset a substantial degree of purchasing power risk with only a small investment in the hedge. Thus, the hedge is defined as more efficient, the higher is $b$.

Many of the assets traditionally considered as good inflation hedges are actually quite inefficient. Consider housing for example. Quarterly data provided by Fama and Schwert (1977) indicate that when unexpected inflation is one percent, the nominal value of housing tends to rise only 0.45 percent. In contrast, a strategy developed below using common stocks for 1974-1979 offers an expected return of 4.2 percent in a period with one-percent inflation $(b=4.2)$. An investment in the common stock hedging strategy could thus offset much more purchasing power risk than an equivalent investment in housing.

Effectiveness. As long as $b>-(1+R)$, a long position in the hedge portfolio can be used to offset at least some purchasing power risk. (Note that $S$ and $w$ in equations (3) and (4) are both positive only when $b>-(1+R)$.) However, a high value of $b$ does not guarantee that the hedge portfolio will offset a substantial amount of total risk. The reason is that, even while offsetting some purchasing power risk, an asset 
h

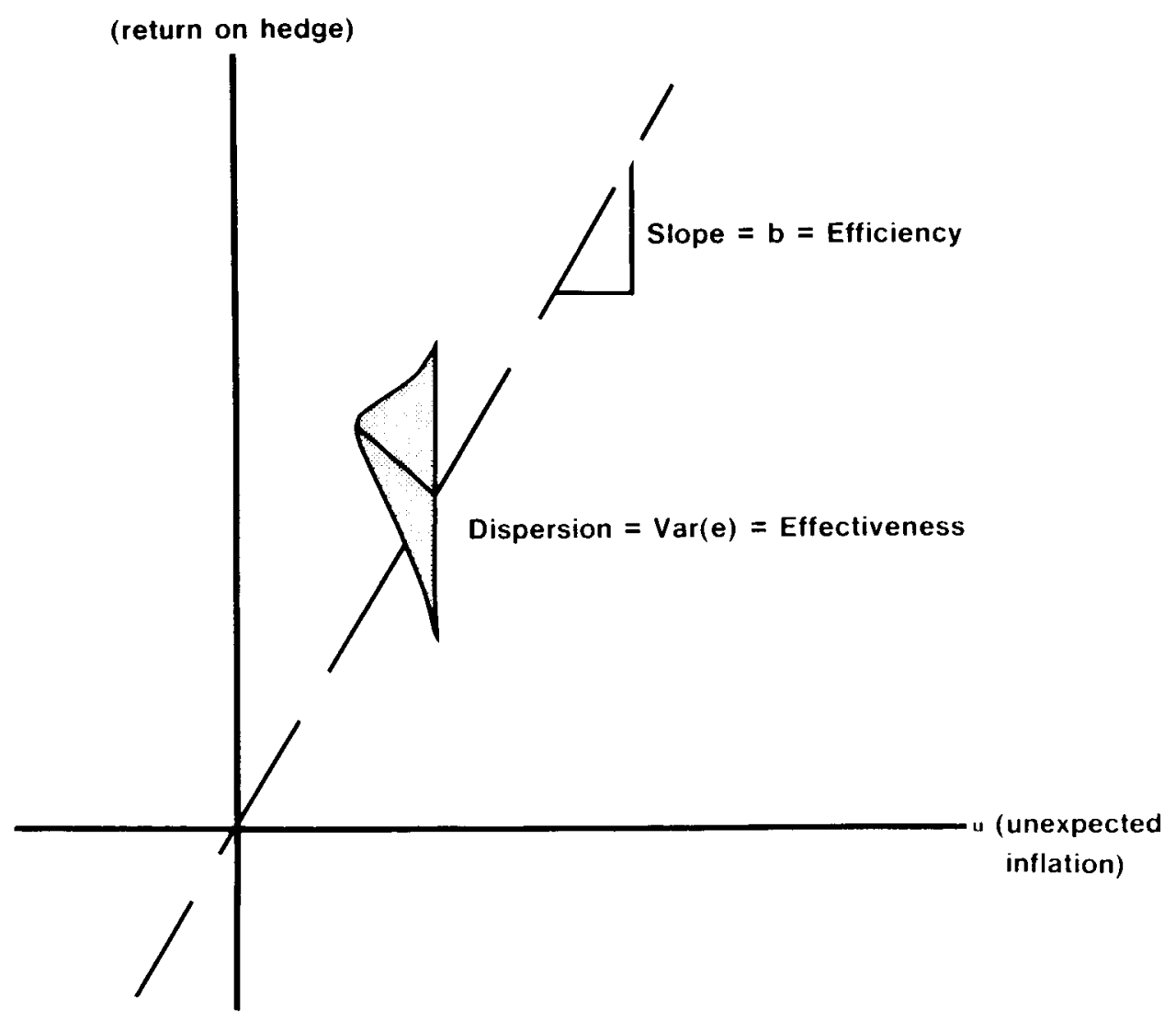

Figure I. Illustration of Hedge Effectiveness and Efficiency.

could introduce new risks such that total risk would not decline significantly. Since the variable $e^{\prime}$ in equation (1) captures variation in the hedge return which is not correlated with unexpected inflation, $\operatorname{Var}\left(e^{\prime}\right)$ is considered a measure of "non-inflation risk." Note that in equation (3), $S$ is shown to be a declining function of $\operatorname{Var}\left(e^{\prime}\right)$. A hedge is defined as effective if it offsets some purchasing power risk, while not adding "too much" non-inflation risk, so that total risk can be substantially reduced.

\section{Common Stocks as Hedges Against Purchasing Power Risk}

Empirical results presented below require estimates of unexpected inflation, $u^{\prime}$. The approach adopted is to assume that unexpected inflation is equal to the difference between the expected and the realized real return on 90-day Treasury bills where inflation is measured by the Consumer Price Index. The approach differs from that of Fama (1975) in that the expected real return is not assumed equal to a constant. The expected real return is forecast using a Box-Jenkins model with moving 
average parameters at lags 1,2 , and 4 . The resulting implied forecasts of expected inflation appear to be unbiased and efficient over the 1960-1979 period.

Estimates of unexpected inflation are subject to measurement error, which would cause coefficients from regressions using those estimates as independent variables to be biased toward zero. Thus, the results should be evaluated while noting that this bias tends to weaken the power of the empirical tests.

Common stocks on average: a poor inflation hedge. Ang, Chua, and Desai (1979), Jaffe and Mandelker (1976), Bodie (1976), Fama and Schwert (1977), and others have shown that common stock indexes covary negatively with unanticipated inflation. These previous results were confirmed and updated through 1979 by regressing real returns of a NYSE index on the estimates of unexpected inflation. During the 1960-1979 period, for every one-percent increase in unexpected inflation, the common stock return tended to fall by over six percent (See Table 1).

Although it is clear that a long position in the stock market portfolio cannot serve as a hedge against unexpected inflation, Bodie (1976) posits that perhaps a short position could serve as a good hedge. Using quarterly data from the 1960-1979 period and equation (3) to compute $S$, a short position in the market could have reduced the total risk associated with a fixed quarterly nominal income stream by less than 18 percent. This reduction in total risk could only be achieved at the expense of the negative expected returns associated with holding a short position in the market portfolio. Even before considering transaction costs, the strategy would be very expensive.

Individual common stocks as inflation hedges. Although the market portfolio as a whole serves as a poor inflation hedge, certain individual stocks or combinations of stocks might possibly provide hedging potential. This possibility is examined using a sample of 571 common stocks for which quarterly returns are available on the CRSP tape from 1960 through 1979.

TABLE 1. Common Stock Index Real Returns* versus Unexpected Inflation.

\begin{tabular}{|c|c|c|}
\hline \multicolumn{3}{|l|}{$1960-1979$ (80 observations) } \\
\hline Quarterly Index Return $=.014$ & $\begin{array}{l}-6.68^{* *} \text { (UNEXPECTED INFLATION) } \\
(-3.58)\end{array}$ & $\begin{aligned} R^{2} & =0.14 \\
\operatorname{Var}(e) & =0.0064\end{aligned}$ \\
\hline \multicolumn{3}{|l|}{ 1960-1969 (40 observations) } \\
\hline Quarterly Index Return $=.016$ & $\begin{array}{l}-5.89 * * \text { (UNEXPECTED INFLATION) } \\
(-2.07)\end{array}$ & $\begin{aligned} R^{2} & =0.10 \\
\operatorname{Var}(e) & =0.0045\end{aligned}$ \\
\hline \multicolumn{3}{|l|}{ 1970-1979 (40 observations) } \\
\hline Quarterly Index Return $=.011$ & $\begin{array}{l}-6.92 * * \text { (UNEXPECTED INFLATION) } \\
(-2.64)\end{array}$ & $\begin{aligned} R^{2} & =0.15 \\
\operatorname{Var}(e) & =0.0086\end{aligned}$ \\
\hline
\end{tabular}

*Based on the NYSE Value Weighted Index obtained from the CRSP Tape.

**Based on $t$ statistics (in parentheses), significant at the $5 \%$ level or less. 
To measure the efficiency of the sample stocks, $b$-coefficients are obtained by regressing the real quarterly returns of each stock against unexpected inflation. Table 2 presents a list of the 20 most efficient and 20 least efficient stocks in the sample over the 1960-1979 period. Note that even the most efficient hedges do not have $b$-coefficients that are significantly positive. In fact, over 73 percent of the sample stocks have $b$-coefficients that are significantly below zero.

Since no individual stock has a significantly positive correlation with unexpected inflation, no single stock can be an efficient hedge. Furthermore, analysis of the individual regressions shows that from 78 percent to 100 percent of this variance in real returns of individual stocks is not explained by unexpected inflation. Thus, most of the risk associated with individual stocks is non-inflation risk, causing individual stocks to be ineffective hedges. Finally, Table 2 indicates that the $b$-coefficients of many individual firms appear to change over time. It appears, then, that no individual stock could provide a hedge against unexpected inflation.

In addition to providing information about the usefulness of individual stocks as inflation hedges, Table 2 allows assessment of the types of firms that are least harmed and most harmed by inflation. The presence of three gold mining companies on the list of most efficient hedges appears to confirm the notion that real values of precious metals are not affected by inflation. Other most efficient stocks include those that sell products for which demand is inelastic, such as oil companies and foods companies. In contrast, the worst (least efficient) hedges include companies that sell products referred to as "non-essential consumption goods." The list includes firms such as Tandy Corporation, Lionel Corporation, Walt Disney Productions, Dr. Pepper Co., and Hilton Hotels. This pattern is also evident in the industry analysis of Table 3 . The best hedges include oil and gas, utilities, groceries, foods, and mining. The worst hedges include retailing, apparel, beverages, motion pictures, and airlines. It appears that during periods of unexpectedly high prices, consumers cope with tight budgets by avoiding expenditures on items such as soft drinks, movies, clothing, and air travel.

\section{A Strategy To Hedge Against Purchasing Power Risk}

Since it is evident that neither the market portfolio nor any individual stock has been a good inflation hedge, a more complex strategy is now presented. The essence of the strategy is to assume a long position in stocks that are predicted to be the "best" hedges and an offsetting short position in the stocks that are predicted to be the "worst" hedges. The combined portfolio should include enough stocks to diversify much noninflation risk. At the same time, such a combination should yield a portfolio with a high $b$-coefficient. Finally, if the systematic risk of the long and short positions are comparable, the scheme represents a zero-expected-return strategy. Thus, the strategy could potentially reduce risk while not affecting expected returns.

Implementing the strategy requires a definition of "best" and "worst" hedges. If individual stocks were ranked according to their inflation $b$-coefficients, the resulting long and short positions would tend not to have comparable systematic market risk. This occurs because both systematic risk and $b$-coefficients are mathematically related to the variance of the return on the individual stock. (See Fama (1976), pages 
TABLE 2. Association of Real Returns with Unexpected Inflation: Individual Firm Analysis.

\begin{tabular}{|c|c|c|c|c|}
\hline Firm & Industry & $\begin{array}{c}1960 \text { 's } \\
b- \\
\text { coefficient }\end{array}$ & $\begin{array}{c}1970 \text { 's } \\
b- \\
\text { coefficient }\end{array}$ & $\begin{array}{c}1960-1979 \\
b- \\
\text { coefficient }\end{array}$ \\
\hline \multicolumn{5}{|c|}{ Twenty Most Efficient Hedges, 1960-1979* } \\
\hline Benguet Corp. & Gold Mining & 3.6 & 6.9 & 5.9 \\
\hline MacAndrews \& Forbes & Paper \& Board Products & 2.6 & 4.2 & 3.8 \\
\hline Atlantic Richfield Co. & Oil \& Gas & 3.2 & 3.3 & 3.2 \\
\hline Standard Oil Co. (Ohio) & Oil \& Gas & 0.3 & 3.8 & 2.9 \\
\hline Homestake Mining & Gold Mining & -1.0 & 2.1 & 1.7 \\
\hline McIntyre Mines, Ltd. & Gold \& Silver Mining & 0.2 & 2.3 & 1.3 \\
\hline $\begin{array}{l}\text { International Mineral \& } \\
\text { Chemical }\end{array}$ & Fertilizers, Chemicals & -8.4 & 3.8 & .7 \\
\hline Pacific Tin & Chemicals, Mining & -2.0 & 2.0 & .5 \\
\hline Kennecott Corp. & Metals, Mining & -6.2 & 3.0 & .3 \\
\hline Enserch Corp. & Gas Distribution & -3.7 & 1.7 & .3 \\
\hline ASA, Ltd. & Gold Mining & -0.1 & 0.5 & .3 \\
\hline Campbell Red Lake Mining & Gold Mining & 0.5 & 0.2 & .3 \\
\hline Keystone Consolidate & Steel \& Metal Fabrication & -6.4 & 2.5 & .2 \\
\hline Campbell Soup Co. & Foods & 4.6 & -1.0 & .2 \\
\hline Archer Daniels Midland & Foods & 1.3 & -0.5 & .0 \\
\hline Holly Sugar Corp. & Foods & -11.3 & 4.2 & -.1 \\
\hline Marathon Oil Co. & Oil \& Gas & -0.8 & 0.0 & -.4 \\
\hline Revere Copper \& Brass & Copper, Brass, Aluminum & -7.0 & 2.1 & -.5 \\
\hline Schlumberger, Ltd. & Oil \& Gas & -1.4 & 0.1 & -.6 \\
\hline Natomas Co. & Mining, Oil \& Gas & 12.0 & -4.2 & -.8 \\
\hline \multicolumn{5}{|c|}{ Twenty Least Efficient Hedges. 1960-1979* } \\
\hline Tandy Corporation & Retail-Electronics & -7.7 & $-31.0^{* *}$ & $-29.4^{* *}$ \\
\hline AVCO Corp. & Conglomerate & $-26.7^{* * *}$ & $-18.2^{* *}$ & $-23.7^{* *}$ \\
\hline Lionel Corp. & Retail-Toys & -16.9 & $-21.0^{* * *}$ & $-23.1^{* *}$ \\
\hline Evans Corp. & Retail-Lumber & $-20.2 * *$ & $-18.2 * *$ & $-22.1 * *$ \\
\hline Trans World Corp. & Airlines & $-19.0 * *$ & $-17.8 * *$ & $-21.0 * *$ \\
\hline Columbia Pictures & Motion Pictures & -1.2 & $-22.9 * *$ & $-20.1 * *$ \\
\hline Cadence Inds. & Drug Stores & -10.0 & $-19.0^{* * *}$ & $-19.1 * *$ \\
\hline Fedders Corp. & Motor Vehicle Parts & 3.5 & $-22.5^{* *}$ & $-18.9 * *$ \\
\hline National Airlines & Airlines & -10.7 & $-17.7 * *$ & $-18.8^{* * *}$ \\
\hline Chris Craft Inds. & Boats-Building \& Repair & $-41.6 * *$ & -6.6 & $-18.7 * *$ \\
\hline MEI Corp. & Soft Drinks (Bottling) & -7.6 & $-18.4 * *$ & $-18.6 * *$ \\
\hline Walt Disney Productions & Motion Pictures, Amusement & -5.6 & $-18.8^{* *}$ & $-18.3^{* *}$ \\
\hline Litton Inds. & Conglomerate & $-16.8^{* *}$ & $-15.2^{* *}$ & $-18.3 * *$ \\
\hline Dr. Pepper Co. & Soft Drinks & $-12.8^{* *}$ & $-15.8^{* *}$ & $-18.2 * *$ \\
\hline Eastern Airlines & Airlines & $-22.6^{* *}$ & $-13.3^{* *}$ & $-18.2 * *$ \\
\hline American Bakeries & Bakery Products & $-13.7 * *$ & $-16.9^{* *}$ & $-18.1 * *$ \\
\hline Pan American & Airline & $-18.7^{* *}$ & $-14.0^{* *}$ & $-17.9 * *$ \\
\hline Royal Crown Co. & Soft Drinks & $-14.7^{* *}$ & $-15.2^{* *}$ & $-17.8^{* *}$ \\
\hline United States Inds. & Apparel & -12.1 & $-15.9 * *$ & $-17.8 * *$ \\
\hline Hilton Hotels Corp. & Hotels & -8.6 & $-17.0^{* *}$ & $-17.7 * *$ \\
\hline
\end{tabular}

* " $b$-coefficients" are regression coefficients derived by regressing real quarterly returns against unanticipated inflation.

**Significantly less than zero at $5 \%$ level, using one-tailed test. 


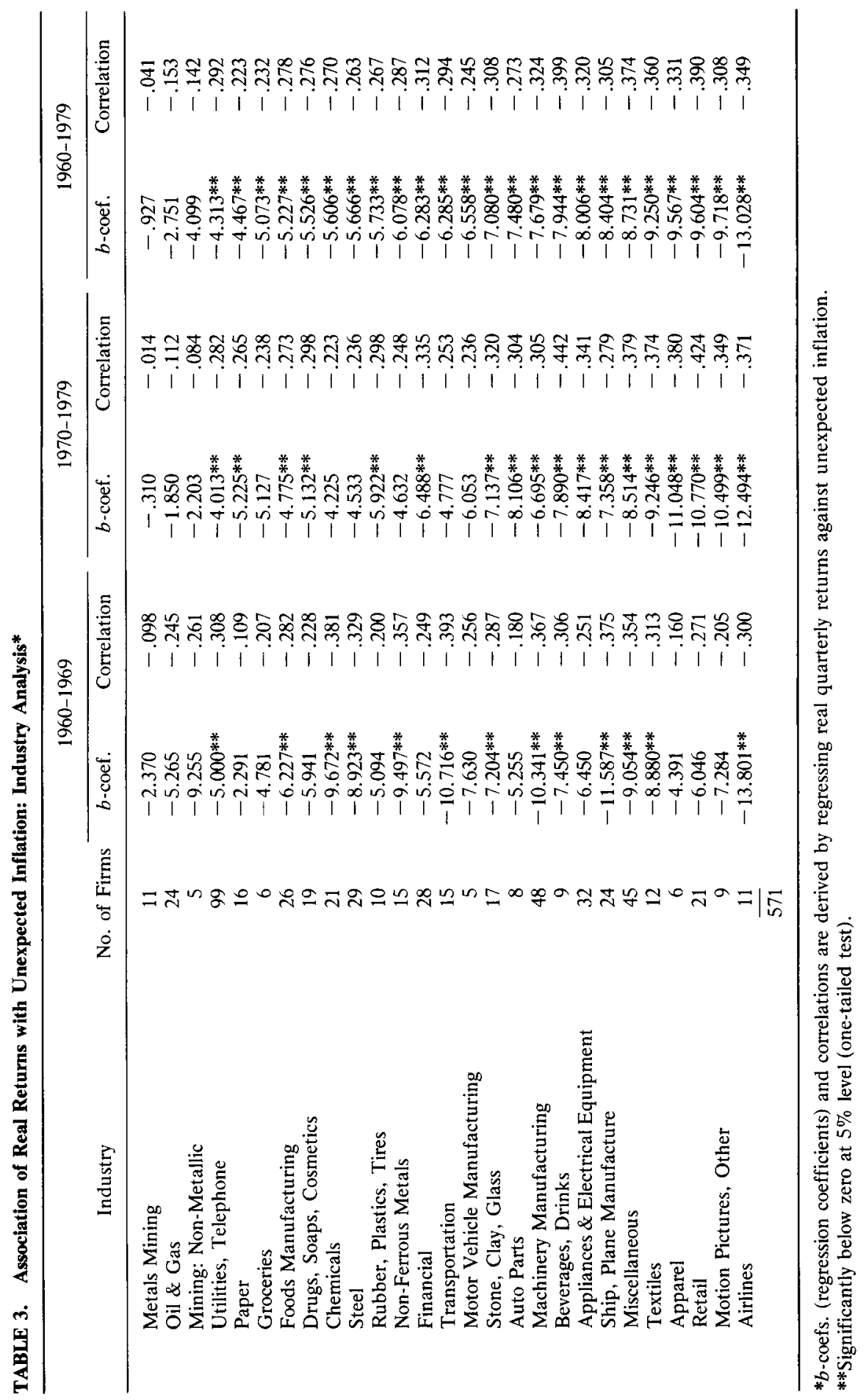


121-124.) This scaling problem can be reduced or eliminated by dividing the $b$-coefficient of each stock by the standard deviation of the stock's return before ranking the stocks. An equivalent ranking is obtained by using correlations of return with unexpected inflation. Here the best (worst) hedges are defined as those with the highest (lowest) correlations of return with unexpected inflation. The resulting long position in the best hedges has systematic risk which is very close to the systematic risk of the worst hedges included in the short position.

The success of the strategy depends on how well one can predict the best and worst hedges. Results are presented here for two cases. First, the investor is assumed clairvoyant and capable of predicting perfectly the 50 stocks with the highest correlations of returns with unanticipated inflation and the 50 stocks with the lowest correlations. This case of perfect foresight provides a measure of the upper limit of hedging potential available in common stocks. How much of that potential can be realized depends on how well the investor can predict correlations of returns with unexpected inflation.

In the second case, historical market data is used to predict the correlation coefficients. This approach is more naive than that which could actually be employed by an investor. Thus, the approach can indicate a lower limit of the hedging potential than can be realized by using common stocks.

To avoid distortion in inflation rates caused by wage and price controls, the strategy is tested only for periods after June, 1974 (Fama (1975), pages 274-275).

Case 1: "Perfect" foresight. Returns of each of the 571 stocks in the sample are regressed against unanticipated inflation, using quarterly data from July 1974 through December 1979. A long position is assumed in the 50 stocks with the highest correlations of real returns with unexpected inflation; a short position is assumed in the $\mathbf{5 0}$ stocks with the lowest correlations. No portfolio revision is allowed over the five and one-half year period.

Regressing the real return on the hedge portfolio against unexpected inflation, the result is:

$$
\begin{aligned}
& \text { Real return on hedge portfolio }=\underset{(.67)}{.010}+\underset{(4.62)}{11.02 \text { (unexpected inflation) }} \\
& \text { ( } t \text {-statistics in parentheses) } \quad R^{2}=.52 \\
& \operatorname{Var}\left(e^{\prime}\right)=.005
\end{aligned}
$$

Note that $11.02=b$, the measure of hedge efficiency, is high. Further, since the $R^{2}$ for the equation is a reasonably high .52, other sources of risk are reasonably moderate. In terms of the earlier graph, the hedge should also be relatively effective. Equations (3) and (4) show this to be true. During the test period, the nominal quarterly return on three-month Treasury bills, $R$, was .017 and the variance of unanticipated inflation, $\operatorname{var}\left(u^{\prime}\right)$, was .00042 . When $b=11.02$ and $\operatorname{var}\left(e^{\prime}\right)=.005$, equations (3) and (4) then imply that $S=55$ percent and $w=4.6$ percent. By investing in the hedge 4.6 percent of the amount invested in Treasury bills, 55 percent of purchasing power risk could have been eliminated. Since all of the risk associated with Treasury bills is purchasing power risk, the strategy would then reduce total risk by 55 percent. 
Although the strategy is designed to yield a zero expected real return, the actual mean real return on the hedge portfolio is 1.7 percent per quarter, due to random error. This is in excess of the mean real return on Treasury bills over this period $(-0.37$ percent per quarter). Thus, during the period examined, the strategy could have reduced total risk while increasing mean return. (Note, however, that the mean return on the hedge portfolio is not significantly different from zero.)

Case 2: Without perfect foresight. The 50 best and 50 worst hedges are now selected on the basis of correlations of unexpected inflation with returns on stocks for the prior six-year period. For example, the predicted 50 best (worst) hedges for 1974 would be the 50 stocks whose correlations were highest (lowest) from 1968 through 1973. A long position is then assumed in the predicted 50 best hedges and a short position is assumed in the predicted 50 worst hedges to form the hedge portfolio held throughout 1974. The 1975 hedge portfolio is constructed on the basis of correlations estimated with 1969-1974 data, and so on. Annual turnover in the hedge portfolio averages about 35 percent.

The return on the hedge portfolio is then calculated for July 1974-December 1979, so that the test period excludes inflation measures that may have been distorted by wage and price controls. Note, however, that the period used to predict the best and worst hedges does include the controls era. While this introduces no bias in the tests, it does reduce their power. However, in spite of this reduction in power, the strategy performs well. When the quarterly real return on the portfolio is regressed against unanticipated inflation, the following estimates are obtained:

$$
\begin{aligned}
& \text { Real return on hedge portfolio }=.007+4.23 \text { (unexpected inflation) } \\
& \text { (.58) (2.17) } \\
& \text { ( } t \text {-statistics in parentheses) } \quad R^{2}=.19 \\
& \operatorname{Var}(e)=.0033
\end{aligned}
$$

As expected, the $b$-coefficient is lower than in the case of perfect foresight. Furthermore, since the $R^{2}$ is only 19 percent, non-inflation risk is a much greater portion of total risk associated with the hedge return. However, whether or not the $b$-coefficient and $R^{2}$ are high enough to allow the hedge to offset much purchasing power risk can be determined only by calculating $S$ and $w$ using equations (3) and (4). When $b=$ 4.23 and $\operatorname{var}\left(e^{\prime}\right)=.0033$, then $S=26$ percent and $w=5$ percent. Thus, the strategy without perfect foresight does indeed offer hedging potential.

A 50-percent margin used to cover a $\$ 50,000$ investment in both the long and short positions in the hedge portfolio, when combined with a $\$ 950,000$ investment in Treasury bills, would offer a variance of real return which is 26-percent lower than the variance of real return associated with a $\$ 1,000,000$ investment in only Treasury bills. Again, while the expected real return on the hedge portfolio is approximately zero, the actual mean real return, due to random error, is about one percent per quarter. Therefore, the hedging strategy, while reducing risk, would have increased the mean real return on Treasury bills from a 0.37 percent loss to a 0.26 percent loss. 
A note on the practical value of the strategy. The practical importance of the research should be assessed while observing that the construction of a successful hedge portfolio does not necessarily involve the use of short sales. Manaster (1979) defines an inflation hedge portfolio as a portfolio that, when combined with a nominally efficient portfolio, yields a real-efficient portfolio. Furthermore, the composition of the hedge portfolio is the same, whether the nominally efficient portfolio includes stocks or is simply a Treasury bill. This paper has examined the case of an investor who holds only Treasury bills in addition to the hedge portfolio. In this case, construction of the hedge portfolio must entail short sales. (Recently developed index futures do, however, provide a vehicle for doing this cheaply. See Figlewski and Kon, 1982.) In the more general case of an investor holding a nominally efficient market portfolio, long and short positions in the hedge stocks are actually just additions to and reductions in long positions in the market portfolio. Thus, it is possible to hedge against unexpected inflation without short-selling.

\section{Conclusion}

In a world of uncertain inflation, a rationale exists for acquiring hedge portfolios. This study provides empirical evidence of the existence of common stock portfolios that were effective and efficient hedges against unexpected inflation over the 1974-1979 period. The results provide evidence which suggests that one can construct, on an ex ante basis, common stock portfolios that have significant hedging potential.

In addition to their practical value, the results have potential implications for capital asset pricing in a multi-period setting. Hedging potential is a necessary but not sufficient prerequisite for the superiority of the multi-period CAPM over the conventional paradigm. Others have met with very little success in demonstrating the existence of inflation hedging potential. In contrast, the results presented here indicate that when hedging strategies depend only on data from recent (six-year) market history, common stock portfolios can serve as hedges against unexpected inflation.

\section{References}

Ang, J. S., Chua, J. H., and Desai, A. S. (1979) "Evidence that the Common Stock Market Adjusts Fully for Expected Inflation." Journal of Financial Research, (Fall), pp. 97-109.

Bernard, V. L. (1982) "Unanticipated Inflation, Real Assets, and the Value of the Firm." Faculty working paper, Graduate School of Business, University of Michigan.

Bernard, V. L. (1983) "The Use of Market Data and Accounting Data in Hedging Against Consumer Price Inflation." Faculty working paper, Graduate School of Business, University of Michigan.

Bodie, Z. (1976) "Common Stocks as Hedges Against Inflation." Journal of Finance, (May), pp. 459-470.

Bodie, Z. (1980) “An Innovation for Stable Real Retirement Income." Journal of Portfolio Management, (Fall), pp. 5-13.

Boonekamp, C. F. (1978) "Inflation, Hedging, and the Demand for Money." American Economic Review, (December), pp. 821-833.

Fama, E. (1975) "Short-Term Interest Rates as Predictors of Inflation." American Economic Review, (June), pp. 269-282. 
Fama, E. (1976) Foundations of Finance, New York: Basic Books, Inc.

Fama, E. and Schwert, W. (1977) "Asset Returns and Inflation." Journal of Financial Economics, (November), pp. 115-146.

Figlewski, S. and Kon, S. J. (1982) "Portfolio Management with Stock Index Futures." Financial Analysts Journal, (January-February), pp. 52-60.

Gouldey, B. K. (1980) "Evidence of Nonmarket Risk Premiums in Common Stock Returns." The Journal of Financial Research, (Fall), pp. 243-260.

Jaffe, J. and Mandelker, H. (1976) "The 'Fisher Effect' for Risky Assets: An Empirical Investigation." Journal of Finance, (May), pp. 447-458.

Long, J. (1974) "Stock Prices, Inflation, and the Term Structure of Interest Rates." Journal of Financial Economics, Volume I, pp. 131-170.

Manaster, S. (1979) “Real and Nominal Efficient Sets.” Journal of Finance, (March), pp. 93-102.

Nelson, C. R. (1973) Applied Time Series Analysis, San Francisco, Calif.: Holden-Day, Inc.

Nelson, C. R. (1976) "Inflation and Rates of Return on Stocks." Journal of Finance, (May), pp. 471-483.

Schipper, K. and Thompson, R. (1981) "Common Stocks as Hedges Against Shifts in the Consumption or Investment Opportunity Set." Journal of Business, (April), pp. 305-328.

Sercu, P. (1981) "A Note on Real and Nominal Efficient Sets." Journal of Finance, (June), pp. 721-737.

Sharpe, W. (1964) "Capital Asset Prices: A Theory of Market Equilibrium Under Conditions of Risk." Journal of Finance, (September), pp. 425-442. 